\title{
Генетические факторы и ремоделирование миокарда у больных сахарным диабетом 2 типа
}

\author{
Углова П. Е., Королева Е. В., Хохлов А. Л., Ильин М. В. \\ ФГБОУ ВО «Ярославский государственный медицинский университет» \\ Министерства Здравоохранения Российской Федерации, Россия, Ярославль
}

\begin{abstract}
Ключевые слова: генетические факторы; ремоделирование миокарда; сахарный диабет 2 типа; полиморфизм генов; полиморфизм гена NOS3

\section{Для цитирования:}

Углова П.Е., Королева Е.В., Хохлов А.Л., Ильин М.В. Генетические факторы и ремоделирование миокарда у больных сахарным диабетом 2 типа // Фармакогенетика и фармакогеномика. 2020;(2):8-9. (In Russ). DOI: $10.37489 / 2588-0527-2020-2-8-9$
\end{abstract}

Введение. Известно, что на развитие сердечно-сосудистых осложнений при сахарном диабете (СД) оказывают влияние индивидуальные генетические особенности, характеризующие чувствительность индивидуума к повреждающему действию патологических факторов [1]. Получены данные о полиморфизме ряда генов, играющих роль в развитии сердечно-сосудистого ремоделирования и хронической сердечной недостаточности [2]. Высокая активность ренин-ангиотензин-альдостероновой системы (РААС), наряду со снижением активности эндотелиальной NO-синтазы, способствует формированию дисфункции эндотелия, развитию ремоделирования сердечно-сосудистой системы, поражению органов-мишеней и возникновению кардиоваскулярных осложнений [3, 4]. Одним из перспективных подходов может стать использование методов генетического тестирования, направленных на выявление генетического риска и прогнозирование осложнений заболевания до появления их клинических проявлений.

Цель. Изучить взаимосвязь частоты встречаемости полиморфизмов генов, ответственных за развитие сердечно-сосудистой патологии, и показателей структурного ремоделирования миокарда левого желудочка у больных сахарным диабетом 2 типа.

Материалы и методы. В исследование включены 50 больных сахарным диабетом 2 типа, в том числе $23(46,0 \%)$ мужчин и $27(54,0 \%)$ женщин. Средний

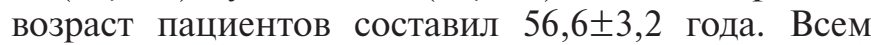
больным выполнялась эхокардиография (ЭхоКГ), проводилось генетическое тестирование, изучение историй болезни, анализ терапии, получаемой пациентами. Показатели эхокардиографии оценивались с помощью ультразвукового сканера Philips «EnVisorC». Для диагностики ремоделирования левого желудочка определялись масса миокарда левого желудочка (ММЛЖ), индекс массы миокарда левого желудочка (ИММЛЖ). Оценка геометрической модели левого желудочка проводилась с учётом ИММЛЖ и индекса относительной толщины левого желудочка (ИОТЛЖ). Исследование полиморфизмов генов проводили методом полимеразной цепной реакции в препаратах ДНК человека, полученных из периферической крови. Комплект предназначен для использования с амплификаторами детектирующими (ООО «НПО ДНК-Технология») ДТ-322, ДТлайт, ДТпрайм и ДТ-96. Для получения ДНК из анализируемого материала использовался комплект реагентов для выделения Проба-Рапидгенетика (ОOО «НПО ДНК-Технология»). Были определены гены, кодирующие элементы ренин-ангиотензин-альдостероновой системы (гены ангиотензиногена, рецептора к ангиотензину II; альдостеронсинтетазы); гены, регулирующие внутриклеточный ионный гомеостаз (Gпротеин бета (3) - субъединица, альфа-аддуктин), а также гены, определяющие структуру эндотелиальной NO-синтазы (NOS3). Анализ данных выполнялся с помощью пакета статистических программ Statistica 10,0 (StatSoft, Inc., USA). Различия данных считались статистически значимыми при значениях $p<0,05$.

Результаты. По результатам нашего исследования установлено, что наличие ремоделирования у пациентов с СД ассоциировано с повышением частоты встречаемости полиморфизма гена NOS3: G894T (Glu298Asp) в виде сочетания мутации-гомозиготы и гетерозиготы на $27,9 \%(p=0,04)$. Кроме того, отмечалась тенденция к увеличению частоты мутации-гомозиготы полиморфизмов генов GNB3: 825 на 17,6 \% и NOS3: T(-786)C на 26,4\% и гетерозиготы полиморфизмов генов AGT: T704C (Met235Thr) на 22,6 \% и AGTR1: A1166C на 16,7 \% при наличии ремоделирования. При сравнительном анализе 
степени ремоделирования в зависимости от полиморфизмов генов выявлено, что эксцентрическая гипертрофия статистически значимо $(p<0,05)$ чаще регистрируется при полиморфизме генов AGTR1: A1166C $(p=0,0003)$ и AGT: T704C (Met235Thr) $(p=0,01)$ со стороны гетерозиготы и мутации гомозиготы гена NOS3: G894T (Glu298Asp) ( $p=0,0001)$, гетерозигота полиморфизма данного гена ассоциирована с выявлением неблагоприятного варианта ремоделирования миокарда левого желудочка концентрической гипертрофии миокарда $(p=0,04)$. Были изучены полиморфизмы генов в зависимости от внутрисердечной гемодинамики, достоверные результаты получены при анализе полиморфизмов генов ADD1: G1378T (Gly460Trp) и NOS3: G894T (Glu298Asp). Для оценки влияния полиморфизмов генов на данные эхокардиографии был использован метод ROC-анализа. Ассоциация полиморфизма гена ADD1: G1378T (Gly460Trp) в виде гетерозиготы (GT) и повышенной ММЛЖ повышает риск развития ремоделирования левого желудочка у больных сахарным диабетом 2 типа с чувствительностью 83,3\% и специфичностью 64,3\%. Ассоциация полиморфизма гена ADD1: G1378T (Gly460Trp) в виде гете- розиготы (GT) и повышенного ИММ ЛЖ повышает риск развития ремоделирования левого желудочка у больных сахарным диабетом 2 типа с чувствительностью 86,1 \% и специфичностью 64,3\%. Ассоциация полиморфизма гена NOS3: G894T (Glu298Asp) в виде мутации гомозиготы (ТТ) и повышенной ИОТЛЖ повышает риск развития ремоделирования левого желудочка у больных сахарным диабетом 2 типа с чувствительностью 88,2 \% и специфичностью 48,5\%. Ассоциация полиморфизма гена NOS3: G894T (Glu298Asp) в виде гетерозиготы (ТT) и повышенной ИОТЛЖ повышает риск развития ремоделирования левого желудочка у больных сахарным диабетом 2 типа с чувствительностью 50,0 \% и специфичностью 88,9\%.

Заключение. Таким образом, развитие структурного ремоделирования сердца может быть связано с полиморфизмом генов, ответственных за фактор эндотелия (NOS3), а также ассоциировано с полиморфизмами генов аддуктина ADD1: G1378T (Gly460Trp) и PAAC (AGTR1: A1166C, AGT: T704C (Met235Thr)), наряду с отсутствием достижения средней суточной дозы препаратов для лечения основной и сопутствующей патологий.

\section{Литература / References}

1. Алексеев И.А., Давыдов Е.Л. Фармакоэпидемиологический анализ антигипертензивной терапии в пожилом и старческом возрасте // Клиническая геронтология. 2018;9-10:5-7. [Alekseev IA, Davydov EL. Pharmacoepidemiological analysis of antihypertensive therapy in elderly and senile age. Clinical gerontology. 2018;9-10:5-7. (In Russ).].

2. Кривощеков С.Г., Суворова И.Ю., Баранов В.И., Шевченко И.В. Генетические предикторы ремоделирования миокарда и работоспособность сердца при гипертонии // Ульяновский медико-биологический журнал. 2017;8(3):135-148. [Krivoshhekov SG, Suvorova IJu, Baranov VI, Shevchenko IV. Genetic predictors of myocardial remodeling and cardiac performance in hypertension. Ulyanovsk Medico-biological Journal. 2017;8(3):135-148. (In Russ).].

3. Саидов М.3., Маммаев С.Н., Абдуллаев А.А. и др. Анализ по-

лиморфизмов генов ренин-ангиотензин-альдостероновой системы и связь с вазопрессорами при эссенциальной артериальной гипертензии с гипертрофией левого желудочка в дагестанской популяции // Российский кардиологический журнал. 2017;10(150):76-84. [Saidov MZ, Mammaev SN, Abdullaev AA et al. Analysis of polymorphisms of renin-angiotensin-aldosterone system and relation to vasopressors in essential systemic hypertension with the left ventricle hypertrophy in dagestan republic. Russ J Cardiol. 2017;10(150):76-84. (In Russ).]. DOI: 10.15829/1560-4071-2017-10-76-84.

4. Boqian Z, Xinmin S, Yaoyao G. An association between the endothelial nitric oxide synthase gene G894T polymorphism and premature coronary artery disease: a meta-analysis. Oncotarget. 2017;8(44):7799077998. 